\title{
British science needs free movement
}

\author{
As the debate on immigration in the UK becomes increasingly visceral, British science risks being caught \\ in the crossfire.
}

By any standard, British academia is remarkably successful. UK institutions rank highly among the world's top universities, and the papers UK academics produce account for a sixth of the world's most highly cited articles. Only the United States has more Nobel Prize winning scientists. Indeed, higher education is one of Britain's major export industries. So when scientists warn this may be coming under threat, policy makers should listen.

Over the past few years, there has been rising concern in the academic community that Britain's tough stance on immigration is putting off the most talented foreign scientists and driving them to competing nations ${ }^{1}$. The latest prominent scientist to add his voice to the rising chorus of criticism is John O'Keefe, the US-born neuroscientist who last month won the Nobel Prize in Physiology or Medicine, who has described Britain's visa rules as a "very, very large obstacle" to recruiting the best scientists from abroad.

Although the bureaucracy for many would-be students is indeed cumbersome, especially for those from outside the European Union (EU), it should be stressed that the UK government has not placed an explicit limit on the number of students from overseas. However, in keeping with the anti-establishment sentiment that has taken hold in many EU countries since the financial crash of 2008, there has been a pronounced rise in anti-immigration rhetoric. With increasing competition for global talent, the perception that the UK does not welcome foreign academics and professionals is becoming problematic.

More worrying still would be the consequences of actually implementing the policies some influential British politicians are floating in the run up to the general election in 2015. Two issues are presently dominating the public discourse: Europe and the poor condition of the UK's public finances, which remain weak despite six years of austerity. By concentrating the discussion on Europe around a more emotive argument about immigration - in particular the government's inability to control migration to Britain because of the EU's rules on the free movement of workers - the

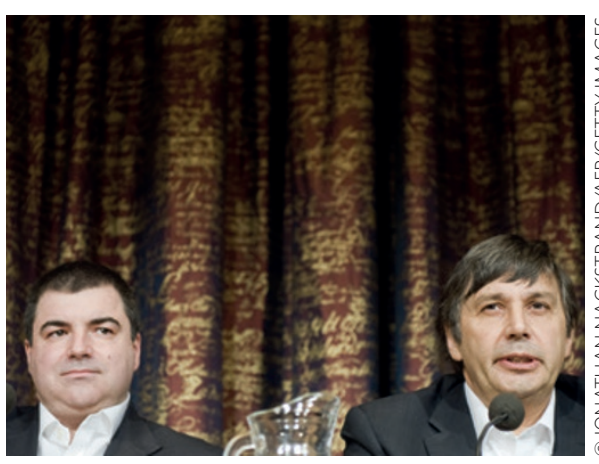

research depends on the open exchange of ideas, and can be greatly undermined if restricted by national borders. Labour mobility is therefore of crucial importance.

Britain is an integral part of a European research landscape in which scientists, knowledge and ideas can move freely across borders. Its cosmopolitan community of academic scientists is renowned for the quality and diversity of research, a fact reflected by the lion's share of grants awarded to them by the European Research Council, the agency that from 2014 to 2020 will fund pioneering research to the tune of $€ 13$ billion as part of the EU's Horizon 2020 programme. The nation is also taking a lead role in the Graphene Flagship project, the $€ 1$ billion collaboration to help bring graphene and other twodimensional materials to commercialization. Famously, graphene shot to prominence as a result of the work carried out by two scientists that came to the UK from abroad: Konstantin Novoselov and Andre Geim (pictured), who were awarded the 2010 Nobel Prize in Physics for their work.

To get an idea of the problems that can result from curbing free movement, Britain need only look at Switzerland. In response to a Swiss referendum that narrowly voted in favour of tight immigration rules that could restrict the number of foreign scientists working in the country, the European Commission suspended talks over Switzerland's association with Horizon 2020 (ref. 3). Although there has since been a thaw in relations and interim solutions have been found, Switzerland's full participation in Horizon 2020 remains in doubt ${ }^{4}$.

Clearly, anti-immigration rhetoric is not just a problem in the UK. But the political debate must focus on facts and not on fear. It is an illusion to think immigration problems will go away following an exit from the EU. Politicians must make clear to the British public that, in a global economy, an open and welcoming policy on immigration is in Britain's economic interest. The success of the country's research depends on it.

\section{References}

1. Cressey, D. Nature 506, 14-15 (2014)

2. Dustmann, C. \& Frattini, T. Econ. J. 124, F593-F643 (2014)

3. Nature 506, 265 (2014)

4. http://cerneu.web.cern.ch/swiss-participation-h2020 